\title{
COMUNICACIÓN
}

\section{Prevalence of Toxocara canis infection in public squares of the Concórdia City, Santa Catarina, Brazil}

\author{
MÁRIO LETTIERI TEIXEIRA*,**, LILIANA PAULA ROSSI*, LUANA DE FREITAS*, \\ NATÁLIA GASPARIN*, SOLANGE PIVA* and ALEXANDRE MENEGHELLO FUENTEFRIA*,**
}

\begin{abstract}
Schools, squares and parks where sand is present can constitute an important transmission form for several parasitic zoonosis, representing a potential risk, mainly for children in school age that play at these places. Among the several zoonosis, visceral larva migrans (VLM), is an important pathology characterized by the migration of the larval stages of Toxocara spp. to human tissues originating imunoalergic type of reactions. The objective of our work was to determine the occurrence of parasites eggs in samples of sands from public squares of Concordia city. This work was accomplished with 12 samples of sand collected at different squares of Concordia: Centro, Nazare, Vista Alegre and Industriarios. $500 \mathrm{~g}$. samples of 4 different places of the same square were collected in plastic flasks and then analyzed by the spontaneous sedimentation exam, proposed by Lutz. A 28\% (7/25) of positive samples for Toxocara canis eggs is demonstrating that the public squares of Concordia represent a high level of environmental contamination for enteroparasites. Such result was anticipated due to the high number of canine population in the municipal district and their easy access to these places.
\end{abstract}

Key words: Toxocara canis, Public Health, Survey, Zoonosis.

\section{INTRODUCTION}

Schools, beaches, squares and parks where sand is present can constitute an important transmission way for several parasitic zoonosis ${ }^{1}$, representing a potential risk, mainly for children at school age that play in these places. Among the zoonosis, visceral larva migrans (VLM), a pathology which is characterized by the migration of the larval stages of Toxocara spp is included. In human tissues originating immunoalergic type of reactions ${ }^{2}$.

The human beings, especially children, are infected by accidentally ingesting Toxocara spp. embrionated eggs present in soil, in fomits and in polluted hands. Perversions of the appetite, as geophagy, are frequent reports in patients with VLM, suggesting that the environmental contamination is the best indicator of the risk for human infection ${ }^{3}$.

Among the helminthes parasites they stand out, for their high prevalence and wide distribution, those that depend on soil transmission, thus denominated earthhelminthes. Their importance depends, fundamentally, on the infected individuals' presence, on fecal contamination of the soil, on favorable conditions for the development of the infective stages, and

* Curso de Farmácia, Universidade do Contestado - Campus de Concórdia.

** Curso de Farmácia, Grupo de Pesquisa em Diagnóstico Laboratorial, Universidade Comunitária Regional de Chapecó - Unochapeco. 
on the potential contact between healthy individuals and polluted soil ${ }^{4}$

In several cities, including Concordia, there are countless dogs walking freely in public places and is very common that, stimulated by their owners, they defecate in these places contaminating the soil with several types of parasites with zoonotic importance. The objective of our work was to determine the occurrence of eggs of parasites in samples of sand from public squares of Concordia city.

\section{MATERIALS AND METHODS}

The study was carried out in Concordia city, State of Santa Catarina, Brazil, in the period of $04 / 12 / 2007$ to $19 / 12 / 2007$. This city has a population. 66.941 inhabitants, according to the Instituto Brasileiro de Geografia e Estatística $(\mathrm{IBGE})^{5}$. A total of 12 samples of sand were collected at different squares of Concordia, in the neighborhoods of Centro, Nazare, Vista Alegre and Industriarios. Approximately $500 \mathrm{~g}$ of samples of 4 different places of the same square, were collected in plastic flasks.

The samples were analyzed by the spontaneous sedimentation exam, proposed by Lutz ${ }^{4}$. A small portion of sand was diluted with deionizaded water, then filtered filtered into a sedimentation glass, using gauzes and funnel. After approximately 30 minutes they were removed using a Pasteur pipette. Two different drops from each sample were used in a same slide, and only one of the drops was stained with lugol. A cover glass was placed and then they were microscopically examined, using lens of 40x.

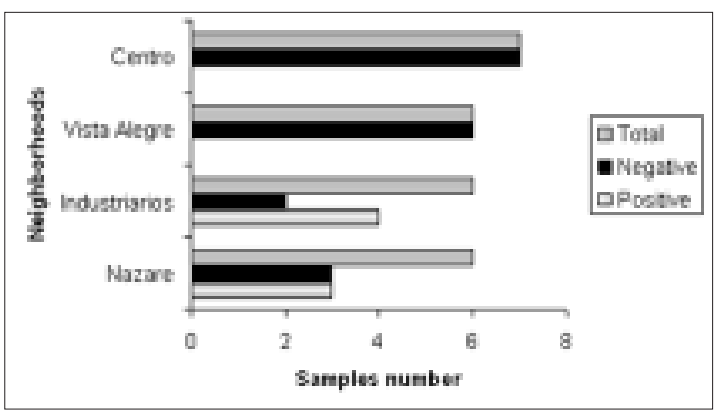

Figure 1. Percentile of positive and negative samples in the neighborhoods of the city of Concordia.

\section{RESULTS}

The samples of the soil collected and processed from the squares of the city of Concordia indicated a $28 \%(7 / 25)$ of positive samples to $T$. canis. Figure 1 shows the places where the samples were collected and the number of positive and negative exams. The collection places were the squares of the neighborhoods Nazare, Industriarios, Vista Alegre e Centro.

\section{DISCUSSION}

In the city of Concordia, the public squares constitute a high level of environmental contamination for enteroparasites. Such result was already expected due to the high number of canine population in the municipal district as well as their easy access to these places. Considering that the sanitary surveillance doesn't have concrete data for the population number of animals, and the presence of many free ones in the streets, the control and resources for the preventing these infections becomes very scarce.

The parasite $T$. canis, causes toxocariasis which can present a variety of manifestations, from asintomatics cases to those with fatal evolution, and they seem to depend on several factors, such as: amount of parasitic load and distribution of the larvae $e^{6}$.

Probably a great number of cases are not diagnosed due to infections with a reduced number of larvae which may be asymptomatic, but there are also severe clinical manifestations in the host due to the inflammatory and hypersensitivity type of reactions in the affected organs ${ }^{6}$.

According to the literature, the rate of infection with $T$. canis in dog kennels is close to $100 \%$, and some of them can produced a high level of soil contamination with eggs of the parasites $^{3,7-9}$.

The squares where this parasite was found are places of leisure, where families spend their weekends, carrying out recreational activities, and where children spend a great deal of their time in contact with the soil, fact that may be quite dangerous as shown by the results of this study. Also, the lack of information on the biological risks that the parents have is an important factor in the infection of $T$. canis. 
Toxocara egg infection in public squares of the Concórdia City, Brazil - M. L. Teixeira et al.

These squares, therefore, should be a concern to the parents, teachers, city hall and of the municipal district as a whole, they should be aware of this sanitary problem with measures dealing with dog access to these public places. Understanding campaigns should be part of the routine of the city, informing mainly in schools, mothers' club and collaborators of the city hall about this pathology. The maintenance of these squares, should also be a priority for the municipal district collaborating with the Health's System in the prevention of these infections and thus stimulating to a better economical development and quality of life.

Therefore, this study ends that the control of animals in public places should be accomplished, with the purpose of preventing pathologies that can attack, mainly, children, especially, in this case, the infection of $T$. canis.

\section{RESUMEN}

Las escuelas, y parques donde existen lugares con arena pueden constituir un camino importante en la transmisión de varias zoonosis parasitarias, representando un riesgo potencial, principalmente para los niños en edad de la escuela que juegan en estos lugares. Entre varias zoonosis, larva migrans visceral (LMV), es una patología caracterizada por la migración de larvas de Toxocara spp. A través de los tejidos del ser humano originando reacciones del topi imunoalergénico. El objetivo de nuestro trabajo fue determinar la presencia de huevos de parásitos en las muestras de arenas de plazas públicas de la ciudad de Concordia. Se trabajó con 12 muestras de arena colectadas de diferentes plazas infantiles de Concordia, de los barrios: Centro, Nazare, Vista Alegre e Industriarios. Una muestra de aproximadamente 500 gramos de 4 lugares diferentes de una misma plaza fueron colocadas en frascos plásticos, siendo luego analizadas mediante el examen de sedimentación espontánea, propuesta por Lutz. Los resultados indicaron un $28 \%(7 / 25)$ de muestras positivas a $T$. canis lo que significa que los suelos de las plazas públicas de la ciudad de Concordia están muy contaminados con huevos de este parásito del perro. Por consiguiente, este estudio señala que debe lograrse un control al acceso de estos animales en los lugares públicos con el propósito de prevenir patologías que pueden afectar principalmente, a niños y sobre todo, en este caso, a la infección por T. canis.

\section{REFERENCES}

1.- CIMERMAN B. Parasitologia humana e seus fundamentos gerais - São Paulo: Ed. Atheneu, 1999.

2.- NUNES C M, PENA F C, NEGRETTI C G S A, et al. Presence of larva migrans in sand boxes of public elementary schools, Brazil. Rev Saude Publica 2000; 34: 656-8

3.- BARRIGA O O. A critical look at the importance, prevalence and control of toxocariasis and the possibilities of immunological control. Vet Parasito 1988; 29: 195-234.

4.- TEIXEIRA M L, FLORES R, FUENTEFRIA, A M. Prevalence of enteroparasites in children of a day care in the city of concordance, SC, Brazil, NewsLab 2006; 78: 110-6.

5.- BRASIL. Instituto Brasileiro de Geografia e Estatística. Avaible at: http://www.ibge.org.br. On: December, 22 , 2007.

6.- FERREIRA W A, AVILA S L M. Diagnóstico Laboratorial das Principais Doenças Infecciosas e AutoImunes, Rio de Janeiro. Ed. Guanabara Koogan, 2001.

7.- SIEVERS G, AMENABARA, GADICKE P. Comparación de cuatro sistemas de muestreo de tierra para determinar contaminación de áreas con huevos de Toxocara canis. Paarasitol Latinoam 2007; 62: 67-71.

8.- FONROUGE R, GUARDIS M, RADMAN N, ARCHELLI S. Contaminación de suelos con huevos de Toxocara $s p$. en plazas y parques públicos de la ciudad de la Plata. Buenos Aires, Argentina. Bol Chil Parasitol 2000; 55: 83-85.

9.- CASTILLO D, PAREDES C, ZAÑARTU C, CASTILLO G. Contaminación ambiental por huevos de Toxocara $s p$. en algunas plazas y parques públicos de Santiago de Chile. 1999. Bol Chil Parasitol 2000; 55: 86-91.
Correspondencia a:

Mário Lettieri Teixeira

Avenida Senador Atílio Fontana, 591, Efapi, 89809-000, Chapecó, Santa Catarina, Brasil.

E-mail:amf77@terra.com.br 